\title{
Investigation of Anti-Microbial Activity of 5-(6-(2,4-Dichlorophenyl)-[1,2,4] Triazolo[3,4-b][1,3,4] Thiadiazol-3-yl)Benzene-1,2,3-Triol
}

\author{
Prerna Chaturvedi' ${ }^{*}$, PK Dubey ${ }^{2}$ and Birendra Shrivastava ${ }^{1}$ \\ ${ }^{1}$ Department of Pharmaceutical Sciences, Jaipur National University, Jaipur, \\ Rajasthan, India \\ ${ }^{2}$ Swami Vivekanand College of Pharmacy, Indore, Madhya Pradesh, India \\ *Corresponding Author: Prerna Chaturvedi, Department of Pharmaceutical \\ Sciences, Jaipur National University, Jaipur, Rajasthan, India
}

Received: April 09, 2020

Published: May 04, 2020

(C) All rights are reserved by Prerna

Chaturvedi., et al.

\begin{abstract}
At present drug discovery includes the identification of screening hits, medicinal chemistry and optimization of these hits to increase the affinity, selectivity (to reduce the potential of side effects), efficacy/potency, metabolic stability (to increase the half-life) and oral bioavailability.

Antimicrobial agents are any variety of c compounds that can destroy or prevent the growth of microorganisms. In the present paper antimicrobial activity of 5-(6-(2,4-dichlorophenyl)-[1,2,4]triazolo[3,4-b][1,3,4] thiadiazol-3-yl)benzene-1,2,3-triol was screened for antimicrobial activity against two representatives of Gram-positive bacteria viz. S. aureus, B. subtilis, two Gram-negative bacteria viz. E. coli, P. aeruginosa and two fungi viz. C. albicans, A. niger by the broth microdilution MIC method. Results suggest that the compound possess optimum activity when compared with standard drug.

Keywords: Anti-Microbial; Triazolo-Thiadiazole Derivative; Standard Drug
\end{abstract}

\section{Introduction}

5-(6-(2,4-dichlorophenyl)-[1,2,4]triazolo[3,4-b][1,3,4] thiadiazol-3-yl)benzene-1,2,3-triol; Yield: 72\%; m.p.: $124-126^{\circ} \mathrm{C}$; $\mathrm{R}_{\mathrm{f}}$ : 0.67; FT-IR $v_{\max }\left(\mathrm{KBr}, \mathrm{cm}^{-1}\right.$ ): 3451 (NH stretching), 3089 (Ar- $\mathrm{CH}$ stretching), 2930 (aliphatic-CH stretching), 1796 (C=0 stretching), 1531 (C=C bending), 1148 (C-O-C stretching), 1317 (CH bending), 1234 (C-N stretching), 1208 (C=N-N stretching), 1067 (O- $\mathrm{CH}_{3}$ stretching), 782 (C-Cl stretching), 748 (substituted benzene), 678 (C-S bending); ${ }^{1} \mathrm{H}$ NMR $\delta\left(\mathrm{CDCl}_{3}, \mathrm{ppm}\right): 6.5$ - 8.2 (m, 11H, aromatic), 5.2 (s, 2H, $-\mathrm{COOCH}_{2}-$ ), $4.4(\mathrm{~s}, 1 \mathrm{H}, \mathrm{NH}), 3.45$ (s, $2 \mathrm{H},-\mathrm{CH}_{2} \mathrm{COO}-$ ), 3.25 (s, 3H, $-\mathrm{OCH}_{3}$ ); $\mathrm{MS}: 540.54\left(\mathrm{M}^{+}, 40 \%\right)$, 470 (30\%), 405 (30\%), 320 (28\%), 285 (48\%), 240 (48\%), 215 (80\%), 180 (36\%), 132 (100\%), 107 (28\%), 77 (50\%). In the present paper anti-microbial activity of 5-(6-(2,4-dichlorophenyl)-[1,2,4]triazolo[3,4-b][1,3,4] thiadiazol-3-yl)benzene-1,2,3triol was evaluated against bacterial and fungal species.

\section{Methodology}

Antimicrobial activity of the compounds and standard drugs were assessed against two representatives of Gram-positive bacteria viz. S. aureus, B. subtilis, two Gram-negative bacteria viz. E. coli, $P$. aeruginosa and two fungi viz. C. albicans, A. niger by the broth microdilution MIC method. Mueller Hinton broth and Sabouraud dextrose broth were used as a nutrient medium to grow and dilute the compound suspension for the test bacteria and fungi, respectively. Ampicillin, Norfloxacin was used as standard antibacterial drugs, whereas fluconazole was used as standard antifungal drug [1-7]. Primary inoculation of bacteria was done into Mueller- Hin-

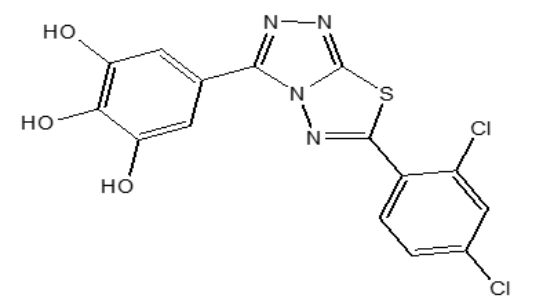

Figure 1: Structure of 5-(6-(2,4-dichlorophenyl)-[1,2,4] triazolo[3,4-b][1,3,4] thiadiazol-3-yl)benzene-1,2,3-triol.

ton agar for overnight growth to produce a number of colonies, which were then directly suspended in saline solution until the turbidity matched the turbidity of the McFarland standard (10 CFU $\mathrm{ml}$ ), i.e. inoculum size for test strain was adjusted to $10^{8}$ colony forming unit (CFU)/ml per well by comparing the turbidity (turbidimetric method). Similar procedure was adopted for fungi with Sabouraud dextrose broth. Dimethyl sulfoxide (DMSO) was used as diluents to get desired concentration of the compounds and standard drugs. Compound and standard drugs were diluted to obtain $500 \mu \mathrm{g} / \mathrm{ml}$ concentrations, as a stock solution. Stock solution was further progressively diluted with the test medium and required concentrations were obtained for primary and secondary screening. In primary screening 500, 250 and $125 \mu \mathrm{g} / \mathrm{ml}$ concentrations of the compounds were tested. The active compounds found in this primary screening were further diluted and tested against the corresponding microorganism. Each test tube was then put for incu- 
bation at $37^{\circ}$ for $24 \mathrm{~h}$ for bacteria and 48 for fungi. Growth or a lack of growth in the tubes containing the antimicrobial agent was determined by comparison with the growth control, indicated by turbidity. The lowest concentration that completely inhibited visible growth of the organism was recorded.

\section{Results, Discussion and Conclusion}

Antimicrobial activity of 5-(6-(2,4-dichlorophenyl)-[1,2,4] triazolo[3,4-b][1,3,4] thiadiazol-3-yl)benzene-1,2,3-triol and standard drugs were assessed against two representatives of Grampositive bacteria viz. S. aureus, B. subtilis, two Gram-negative bacteria viz. E. coli, P. aeruginosa and two fungi viz. C. albicans, A. niger by the broth micro-dilution MIC method. Ampicillin was used as standard antibacterial drugs, whereas fluconazole was used as standard antifungal drug. The results obtained as mentioned in table 1 revealed that compounds exhibit antibacterial activities against both Gram-positive strains. The obtained results for antifungal activities as depicted in table 1 revealed that compounds could inhibit the growth of the tested fungal strains.

\begin{tabular}{|l|c|c|c|c|c|c|}
\hline \multirow{2}{*}{ Compound } & \multicolumn{6}{|c|}{ MIC, $\mu \mathrm{g} / \mathrm{ml}$} \\
\cline { 2 - 7 } & S. aureus & $\begin{array}{c}\text { B. sub- } \\
\text { tilis }\end{array}$ & $\begin{array}{c}\text { P. aerugi- } \\
\text { nosa }\end{array}$ & $\begin{array}{c}\text { E. } \\
\text { coli }\end{array}$ & $\begin{array}{c}\text { A. } \\
\text { niger }\end{array}$ & $\begin{array}{c}\text { C. albi- } \\
\text { cans }\end{array}$ \\
\hline Compound & 24.2 & 20.2 & 18.6 & 18.0 & 24.8 & 30.2 \\
\hline Ampicillin & 10.6 & 10.8 & - & - & - & - \\
\hline Norfloxacin & 11.8 & 14.2 & 10.4 & 7.8 & - & - \\
\hline Fluconazole & - & - & - & - & 9.6 & 10.4 \\
\hline
\end{tabular}

Table 1: Minimum inhibitory concentration

(MIC, $\mu \mathrm{g} / \mathrm{ml}$ ) of compounds.

\section{Bibliography}

1. Colanceska-Ragenovic K., et al. "Synthesis, antibacterial and antifungal activity of 4-substituted5-aryl-1,2,4-triazoles". Molecules 6.10 (2001): 815-824.

2. Demirbas N., et al. "Synthesis and antimicrobial activities of some new 1-(5-phenylamino-[1,3,4]thiadiazol-2- yl)methyl5-oxo-[1,2,4]triazole and 1-(4-phenyl-5- thioxo-[1,2,4]triazol3-yl)methyl-5-oxo-[1,2,4]triazole derivatives". European Journal of Medicinal Chemistry 39.9 (2004): 793-804

3. El-Sayed WA., et al. "C-Furyl glycosides, I: Synthesis and antimicrobial evaluation of C-furyl glycosides and chalcones derived therefrom". Monatshefte für Chemie 139 (2008): 14991505.

4. El-Sayed WA., et al. "C-Furyl glycosides, II: Synthesis and antimicrobial evaluation of C-furyl glycosides bearing pyrazolines, isoxazolines, and 5,6-dihydropyrimidine2(1H)-thiones". Monatshefte für Chemie 140 (2009): 365-370.

5. Greenwood D. "Antimicrobial Chemotherapy, $4^{\text {th }}$ edition". Oxford University Press, New York (2000): 114.
6. Jatav V., et al. "Synthesis and Antimicrobial activity of Novel 2-Methyl-3-(1,3,4- thiadiazolyl)-4-(3H)Quinazolinones". Indian Journal of Pharmaceutical Sciences 68.3 (2006): 360-363.

7. Liu F., et al. "Synthesis and antifungal activity of novel sulfoxide derivatives containing trimethoxyphenyl substituted 1,3,4thiadiazole and 1,3,4-oxadiazole moiety". Bioorganic and Medicinal Chemistry 16.7 (2008): 3632-3640.

\section{Assets from publication with us}

- Prompt Acknowledgement after receiving the article

- Thorough Double blinded peer review

- Rapid Publication

- Issue of Publication Certificate

- High visibility of your Published work

Website: https://www.actascientific.com/

Submit Article: https://www.actascientific.com/submission.php Email us: editor@actascientific.com

Contact us: +919182824667 